\title{
Spatio-temporal variations in water quality, hydrochemistry and its controlling factors in a perennial river in India
}

\author{
Raj Setia $^{1} \cdot$ Shaveta Lamba $^{1} \cdot$ Shard Chander ${ }^{2} \cdot \operatorname{Vinod~Kumar}^{3} \cdot$ Randhir Singh $^{1} \cdot$ P. K. Litoria ${ }^{1} \cdot$ R. P. Singh ${ }^{2}$. \\ Brijendra Pateriya ${ }^{1}$
}

Received: 13 November 2020 / Accepted: 16 September 2021 / Published online: 3 October 2021

(c) The Author(s) 2021

\begin{abstract}
The spatial and temporal variations in the hydrochemistry of the Sutlej river in the Indian Punjab were studied based on water quality parameters analysed during pre- and post-monsoon seasons of the years 2017 and 2018 . The grab water samples were collected from the river using stratified random sampling and analysed for $\mathrm{pH}$, electrical conductivity (EC), carbonate $\left(\mathrm{CO}_{3}{ }^{-2}\right)$, bicarbonate $\left(\mathrm{HCO}_{3}^{-}\right)$, chloride $\left(\mathrm{Cl}^{-}\right)$, nitrate $\left(\mathrm{NO}_{3}^{-}\right)$, total hardness, calcium $\left(\mathrm{Ca}^{+2}\right)$, sodium $\left(\mathrm{Na}^{+}\right)$and potassium $\left(\mathrm{K}^{+}\right)$using standard methods. Spatio-temporal variations in the parameters used to evaluate the water quality for irrigation (electrical conductivity (EC), residual sodium carbonate (RSC) and sodium absorption ratio (SAR)) were also studied. In order to rate the composite influence of all the physicochemical parameters, water quality index (WQI) was computed. Spatial variations in WQI for drinking and irrigation purposes were studied using the inverse distance weighted method in GIS. Results showed that the river water was alkaline in nature, $\mathrm{HCO}_{3}{ }^{-}$and $\mathrm{Cl}^{-}$are the major anions, and $\mathrm{Ca}^{2+}$ and $\mathrm{Na}^{+}$ are the cations in the river water during both seasons. The regression analysis of $\mathrm{EC}$ with cations and anions showed that the regression coefficient was mainly significant with $\mathrm{Ca}^{2+}$ and $\mathrm{HCO}_{3}{ }^{-}$, irrespective of the season. The concentration of ions was not significantly affected by season, but it was higher along transboundary of the river. Total alkalinity of water was significantly $(p<0.05)$ higher during pre-monsoon than post-monsoon season. The EC, SAR and RSC values during different seasons showed that $>85 \%$ of the water samples were in good categories for irrigation purposes. According to grades of WQI for drinking purposes, the poor WQI was observed in 3.6\%, 3.7\% and 5.9\% of the samples during pre-2017, pre-2018 and post-monsoon 2018, respectively. The poor water quality index for irrigation purposes was observed in $16.7 \%$ and $4.7 \%$ of the samples during pre-monsoon 2017 and 2018, respectively. The water quality index values for drinking and irrigation were higher (poor water quality) along transboundary of the river. The ratio of $\mathrm{Ca}^{2+} / \mathrm{Mg}^{2+},\left(\mathrm{Na}^{+}+\mathrm{K}^{+}\right) / \mathrm{T}_{\mathrm{Z}}^{+}$and $\mathrm{Ca}^{2+}+\mathrm{Mg}^{2+} /\left(\mathrm{Na}^{+}+\mathrm{K}^{+}\right)$indicated both carbonate and silicate lithology contribute to hydrochemistry of the river besides anthropogenic factors. Non-metric multidimensional scaling showed that all the samples are of a similar origin across the river including transboundary, whereas cluster analysis resulted in the two main groups: $\mathrm{pH}$ and $\mathrm{Cl}$ in the one group, and $\mathrm{EC}$ along with the remaining cations and anions in the other group during pre-monsoon, but $\mathrm{pH}$ in the one group, and $\mathrm{EC}$ along with the remaining cations and anions in the other group during post-monsoon. The high concentration of $\mathrm{Cl}^{-}$is a signature of anthropogenic inputs in addition to the contribution of natural factors. These results suggest that the cultivation of crops on the soils along transboundary may cause the transfer of ions through the food chain to human beings affecting their health. Moreover, drinking of river water by inhabitants living along transboundary may affect their health.
\end{abstract}

Keywords Drinking water quality $\cdot$ Geographic information system $\cdot$ Hydrochemistry $\cdot$ Irrigation water quality $\cdot$ Sutlej river · Water quality index

Raj Setia

setiark@gmail.com

Punjab Remote Sensing Centre, Ludhiana, India

Space Applications Centre, ISRO, Ahmedabad, India

3 Department of Botany, Government Degree College, Ramban, Jammu, India

\section{Introduction}

The natural condition of the river is regulated by complex anthropogenic aspects such as urban growth and development, agronomic and industrial activities, chemical leak coincidences and dam constructions, and natural activities 
like climatic circumstances and weathering processes, etc. (Gao et al. 2017; Mainali and Chang 2018; Yegemova et al. 2018). This altered water quality of rivers has harmful effects on trophic levels of the aquatic environment in a river (Khatri and Tyagi 2015). Water quality evaluation studies are considered as one of the thrust areas in the water resources sector (Jiang et al. 2020). The proper understanding of seasonal and spatial variability of water quality is important to meet the increasing demand and also to formulate the plan for sustainable management of water resources (Haji et al. 2021; Poudel et al. 2013; Spencer et al. 2008).

The use of good quality river water for irrigation may improve plant growth (Bauder and Brock 2001) because cations and anions in the river water supply few essential nutrients to plants in readily available form (White and Brown 2010). However, the excessive concentration of soluble salts in water may cause hazards for irrigation (Elgallal et al. 2016; Zaman et al. 2018). The saline or alkalinity of water is determined by the association of sodium and calcium with carbonate/bicarbonate or chloride/sulphate (Logeshkumaran et al. 2015). The major sources of these anions are fertilizers, rocks, agricultural, domestic and industrial effluents (Kazi et al. 2009; Selvakumar et al. 2017). Chloride ions are not generally adsorbed by soils which cause it readily movement with the soil-water (White and Broadley 2001). This results in chloride uptake by crop followed by its movement in the transpiration stream and accumulation in plant leaves. Though sulphate in irrigation water is beneficial for soil fertility, but it also contributes to soil salinity (Curtin et al. 1993). The high concentration of carbonate and bicarbonate in irrigation water produces harmful effects in soils due to the reaction of these anions with calcium leading to formation of calcium carbonate (Shahabi et al. 2005). When water is evaporated, calcium carbonate is precipitated which causes less availability of calcium in soils. Both calcium and magnesium cause flocculation of soil particles, whereas high concentration of sodium ions causes dispersion of soil particles (Warrence et al. 2002). In addition to irrigation, river water is used for drinking purposes and plays a vital role in ecosystem safety and human health (Carr and Neary 2008).

For sustainable development of any region, information on available water resources needs to be suitably merged with water quality data in a Geographic Information System (GIS) environment to arrive at location-specific prescriptions for optimum utilization of these resources (Aravindan and Shankar 2011; Balamurugan et al. 2020; Kamble et al. 2020; Shankar et al. 2010). Geostatistics along with GIS uses the spatial coordinates of observations into the data set for modelling the spatial patterns and also estimating the variable values at unsampled locations (Burrough 2001; Moral 2010). Spatial interpolation methods like kriging and inverse distance weight (IDW) techniques are generally used for mapping and monitoring of surface water quality
(Chabuk et al. 2020; Mirzaei and Sakizadeh 2016). Many studies have found that IDW is better than other techniques for monitoring of water quality (Kamble et al. 2020; Pande and Moharir 2018; Rodríguez et al. 2021; Selvam et al. 2014).

The Sutlej river in Indian Punjab is contaminated by the release of industrial and domestic wastes, and agronomic runoff which is accumulated in the river and neighbouring land (Jindal and Sharma 2011; Setia et al. 2020a). The river water is used for irrigation and drinking purposes, mainly in the south-western parts of the Indian Punjab (Setia et al. 2020b, 2021; Singh et al. 2011). Therefore, assessing the hydrochemistry of surface water of the river is important for evaluating the hydrogeochemical and other processes involved in spatial and temporal changes in the river's water quality. The contamination of the Sutlej river due to anthropogenic and industrial waste not only deteriorates the water quality (Jindal and Sharma 2011) but also imperils the balance in ecosystems, economic development, social prosperity and human health (Setia et al. 2020a; Singh et al. 2013). However, few studies have assessed the water quality of the Sutlej river in a small stretch of the river (Sharma and Walia 2017; Singh and Sharma 2020), but there is no systematic study on spatio-temporal variations in water quality and hydrochemistry of water in the entire stretch of the river flowing in Indian Punjab including transboundary of the river. Therefore, seasonal and spatial variations in the hydrochemistry of the river water were assessed during pre-monsoon and post-monsoon seasons of the years 2017 and 2018 using water quality indices, hydrochemistry, non-metric multidimensional scaling, cluster analysis and GIS. The objectives of the study were to (1) assess spatial and temporal variations in hydrochemistry $\left(\mathrm{pH}, \mathrm{EC}, \mathrm{Ca}^{2+}\right.$, $\mathrm{Mg}^{2+}, \mathrm{K}^{+}, \mathrm{Na}^{+}, \mathrm{CO}_{3}{ }^{2-}, \mathrm{HCO}_{3}{ }^{-}, \mathrm{Cl}^{-}$and $\mathrm{NO}_{3}{ }^{-}$) of water, (2) determine the suitability of river water for irrigation and drinking purposes, and (3) study the factors controlling the hydrochemistry of river.

\section{Materials and methods}

\section{Study area}

The Sutlej river is one of the most important tributaries of the Indus river. In Indian Punjab, the river enters Nangal and passes through few districts (Ropar, Jalandhar, Ludhiana and Moga), followed by merging with Beas river at Harike (the Ramsar Wetland). After passing through Harike, Firozpur and Fazilka, the river leaves India and enters into Pakistan. The Sutlej river is polluted by industrial and domestic effluents and agricultural runoff which are generally released into the river or adjacent regions. The water samples were collected from the river and classified into the four zones 
on the basis of the extent of contamination and colour of water observed from the Landsat- 8 satellite imagery: Zone-I (Gobind Sagar), Zone-II (from Gobind Sagar to the confluence of Buddha Nullah and Sutlej river), ZoneIII (from the confluence of Buddha Nullah and Sutlej river to the transboundary) and Zone-IV (Sutlej river along the transboundary).

The climate of Punjab is mainly influenced by the Himalayas in the north and the Thar Desert in the south and southwest. The periodic circulation of the moist air masses from the south-east and north-western sectors decides the occurrence of two wet periods each followed by a dry period. The presence of Himalayas in the north greatly modifies the temperature. The temperature increases and rainfall decreases as the distance from the Himalayas increases. In general, summers are hot and winters are cool. There are three distinct seasons in the Indian Punjab: Hot season from April to June, Rainy season from July to September and Winter season from October to March. Geologically, the Indian Pun$\mathrm{jab}$ is formed by the alluvial deposits of various rivers like Beas, Sutlej, Ravi Ghaggar and their tributaries. The area is comprised of three stratigraphic units from north to south: Siwaliks, piedmont and alluvial plain. The Siwalik hills are formed as a result of the latest phase of Himalayan orogeny. These are composed of Pinjore boulder beds, conglomerates and poor lithified, soft and friable-sand stone and shales. The age of these deposits varies from upper Miocene to lower Pleistocene. The piedmont plain (Kandi Belt) is characterized by coarse-textured, poorly sorted, gravel and pebbles. It is formed due to coalescence of alluvial fans and confined to narrow belt along the Siwalik foot hills. Barring the Siwaliks in the north eastern part, the entire Indian Punjab is covered with the Quarternary sediments deposited by the ancient river system, forming a part of the vast Indus Alluvial plain. The fluvial sediments are mostly represented by alternate beds of sand, silt and clay inter mixed with gravels, pebbles and kankar in varying proportion. Based upon their location of deposition, these can be further subdivided into recent, newer and older alluvial deposits.

\section{Water sampling}

The grab (taken at a selected location) water samples $(N=76)$ were collected from Sutlej river during pre-monsoon (May) and post-monsoon (September-October) of the years 2017 and 2018 using stratified random sampling (Fig. 1). The bottles were thoroughly washed 2-3 times with water to be sampled during sampling. The samples were carried and stored in sterile polythene bottles in the laboratory at $\left(<4{ }^{\circ} \mathrm{C}\right)$ temperature as per recommended protocols of the American Public Health Association (APHA, 1998).

\section{Analysis of water samples for physicochemical parameters}

The water samples were analysed for $\mathrm{pH}$, electrical conductivity (EC), carbonate $\left(\mathrm{CO}_{3}{ }^{-2}\right)$, bicarbonate $\left(\mathrm{HCO}_{3}{ }^{-}\right)$, chloride $\left(\mathrm{Cl}^{-}\right)$, total hardness, calcium $\left(\mathrm{Ca}^{+2}\right)$, sodium $\left(\mathrm{Na}^{+}\right)$and potassium $\left(\mathrm{K}^{+}\right)$using the standard procedure given in American Public Health Association (APHA, 1998) within $24-48 \mathrm{~h}$ of sampling. The $\mathrm{pH}$ electrode (Mettler Toledo FiveEasy plus $\mathrm{pH}$ meter) was calibrated using 3 buffer solutions ( $\mathrm{pH} \mathrm{4,} \mathrm{pH} 7$ and $\mathrm{pH} 9.2$ ), and EC was measured using a pre-calibrated meter (Mettler

Fig. 1 Sampling Locations

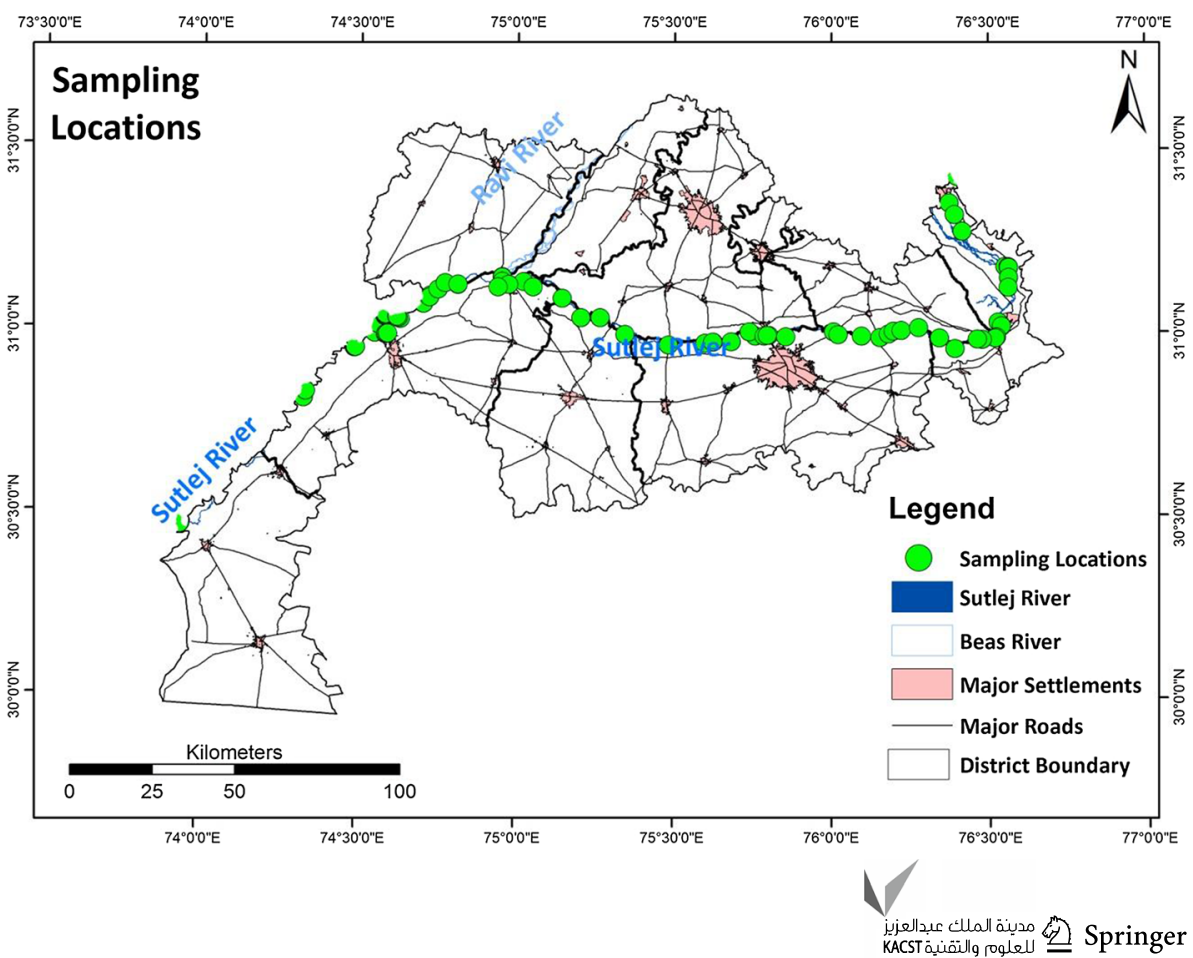


Toledo FiveEasy plus Conductivity meter). The accuracy of $\mathrm{pH}$ analysis of water samples was checked after every seven samples using standard buffer solutions of $\mathrm{pH} 7$ and 9.2, whereas the accuracy of EC analysis was checked using standard EC solution of $1413 \mathrm{Ms} \mathrm{cm}^{-1}$. Major anions such as $\mathrm{CO}_{3}{ }^{2-}$ and $\mathrm{HCO}_{3}{ }^{-}$were measured using acid titration method, chloride by the $\mathrm{AgNO}_{3}$ titration method, nitrate using a UV-visible spectrophotometer (Systronics UV-visible spectrophotometer 117) and sulphate by the $\mathrm{BaCl}_{3}$ method using a turbidity meter (Systronics $\mu \mathrm{C}$ Turbidity meter 135). Major cations such as $\mathrm{Ca}^{+2}$ and $\mathrm{Mg}^{+2}$ were analysed by the titration method and $\mathrm{Na}^{+}$and $\mathrm{K}^{+}$by a flame photometer (Elico CL 378 Flame Photometer). The concentration of magnesium $\left(\mathrm{Mg}^{+2}\right)$ was calculated by subtracting $\mathrm{Ca}^{+2}$ from total hardness. The total alkalinity of water was calculated using the following formula:

Total alkalinity as $\mathrm{CaCO}_{3}=50.04 \times\left[\left(\mathrm{HCO}_{3}{ }^{-} \times 0.1639\right)\right.$ $\left.+\left(\mathrm{CO}_{3}{ }^{2-} \times 0.03323\right)\right]$ where all units are in $\mathrm{mg} / \mathrm{L}$.

The precision of all the physicochemical parameters was checked by analysis of duplicate samples.

The concentrations of cations and anions in the water should balance because water must be electrically neutral. The charge balance was calculated using the following equation:

Electro - Neutrality (E.N. in $\%)=\frac{\left(\sum \text { cations }-\sum \text { anions }\right)}{\left(\sum \text { cations }+\sum \text { anions }\right)} \times 100$

The concentration of cations in $\mathrm{mg} / \mathrm{L}$ was converted to $\mathrm{meq} / \mathrm{L}$, and the E.N. of all the samples was within the acceptable limits of $\pm 5 \%$ (Hounslow 1995).

\section{Calculation of indices for assessing the surface water quality for irrigation purposes}

The suitability of surface water for irrigation purpose was evaluated based on the following indices:

\section{Sodium absorption ratio (SAR)}

SAR determines the relative fraction of $\mathrm{Na}^{+}$ions to the $\mathrm{Ca}^{2+}$ and $\mathrm{Mg}^{2+}$ ions in the water samples. It signifies the sodium hazard and calculated using the following equation:

$\mathrm{SAR}=\frac{\mathrm{Na}^{+}}{\sqrt{\frac{\mathrm{Mg}^{2+}+\mathrm{Ca}^{2+}}{2}}}$

On the basis of SAR values, Richards (1954) categorized the water in four types: excellent $(<10)$, good $(10-18)$, doubtful/fair poor (19-26) and unsuitable ( $>26)$.

\section{Sodium percentage ( $\mathrm{Na} \%)$}

Sodium percentage or soluble sodium percent is computed using the following equation (Wilcox 1955):

$\% \mathrm{Na}=\frac{\mathrm{Na}^{+} \times 2}{\left(\mathrm{Ca}^{2+}+\mathrm{Mg}^{2+}+\mathrm{Na}^{+}+\mathrm{K}^{+}\right)}$

If $\mathrm{Na} \%<60$, water is classified as safe and trouble from excess $\mathrm{Na}$ will not occur on the soil. If $\mathrm{Na} \%>60$, water is classified as unsafe, and the excess $\mathrm{Na}$ will affect soil physical fertility.

\section{Residual sodium carbonate (RSC)}

The amount of $\mathrm{CO}_{3}{ }^{2-}$ and $\mathrm{HCO}_{3}{ }^{-}$in excess of alkaline earth metals $\left(\mathrm{Ca}^{2+}\right.$ and $\left.\mathrm{Mg}^{2+}\right)$ is represented by $\mathrm{RSC}$, which is calculated using the following equation:

$\mathrm{RSC}=\left(\mathrm{CO}_{3}^{2-}+\mathrm{HCO}_{3}^{-}\right)-\left(\mathrm{Ca}^{2+}+\mathrm{Mg}^{2+}\right)$

\section{Kelly's index (KI)}

This index is computed using the following equation (Kelly 1940):

$\mathrm{KI}=\frac{\mathrm{Na}^{+}}{\left(\mathrm{Ca}^{2+}+\mathrm{Mg}^{2+}\right)}$

The KI values less than one signifies water is suitable for irrigation, whereas KI values above one show that water is not suitable for irrigation (Sundaray et al. 2009).

\section{Permeability index}

Water with a higher concentration of $\mathrm{HCO}_{3}$ and $\mathrm{CO}_{3}$ reacts with $\mathrm{Ca}^{2+}$ and $\mathrm{Mg}^{2+}$ in soil solution. This results in precipitations of these cations as calcite and magnesite, which causes adsorption of sodium onto the clay surfaces, thereby increasing sodium hazard. This reduces soil permeability and inhibition of root penetration, etc. (Todd and Mays 2005). Therefore, the permeability index (PI) was calculated using the following equation:

$\mathrm{PI}=\frac{\mathrm{Na}^{+}+\sqrt{\mathrm{HCO}_{3}^{-}}}{\left(\mathrm{Ca}^{2+}+\mathrm{Mg}^{2+}+\mathrm{Na}^{+}\right)} \times 100$

\section{Water quality index (WQI)}

In order to rate the composite influence of all the physicochemical parameters, water quality index (WQI) 
was calculated using the following equation (Kawo and Shankar 2018):

$\mathrm{WQI}=\frac{\sum_{i=1}^{n} W_{i} Q_{i}}{\sum_{i=1}^{n} W_{i}}$

$W_{i}=\frac{K}{S_{i}}$

$Q_{i}=\frac{V_{a}-V_{i}}{V_{s}-V_{i}}$

where $W_{i}=$ unit weight for $n$th parameter, $Q_{i}=$ quality rating, $S_{i}=$ standard permissible value for $n$th parameter, $V_{a}=$ actual value of the water quality parameter obtained from laboratory analysis, and $V_{i}=$ ideal value of the quality parameter. The standard permissible limit and unit weight of each parameter and index for drinking and irrigation purposes is given in Table 1. In general, the relative weighting (wi) must be assigned to the water quality parameters having the potential to cause significant effects on human health and also on plant growth (Haji et al. 2021; Kawo and Shankar 2018). In this study, the highest weight $\left(W_{i}\right)$ was assigned for $\mathrm{NO}_{3}{ }^{-}$and $\mathrm{EC}$ and the $\mathrm{W}_{\mathrm{i}}$ for the remaining parameters was in the order: $\mathrm{pH}>\mathrm{Cl}^{-}=$Total alkalinity $>\mathrm{Ca}^{2+}=\mathrm{Mg}^{2+}=\mathrm{Na}^{+}=$Total Hardness $>\mathrm{K}^{+}$. The water was classified into five categories based on the WQI values: excellent water $(<50)$, good water $(50-100)$, poor water (100-200), very poor water (200-300), and unsuitable for drinking (>300).
The spatial and temporal variations in WQI of water samples for drinking and irrigation purposes were studied using the inverse distance weighted (IDW) method in ArcGIS 10.4. Inverse distance weighted (IDW) uses the linear weighted combination of values at known points to estimate the unknown values of the surrounding sample points (Yang et al. 2020). The weight in IDW is inverse function of the distance (Ogbozige et al. 2018). In IDW, the values at unknown location $Z\left(S_{0}\right)$ are determined by the weighting value $\lambda_{i}\left(S_{0}\right)$ and values at known location $Z\left(S_{i}\right)$. This can be expressed using the following equation:

$Z\left(a_{0}\right)=\sum_{i=1}^{n} \lambda_{i}\left(S_{0}\right) \cdot Z\left(S_{i}\right)$

The weights $\lambda_{i}$ are estimated through inverse distance from all points to the new points using the following equation:

$\lambda_{i}\left(a_{0}\right)=\frac{1 / \beta d\left(S_{0}, S_{i}\right)}{\sum_{i=1}^{n} 1 / \beta d\left(S_{0}, S_{i}\right)} ; \beta>1$

where $\lambda_{i}=$ weight for neighbour $i$ (Ideally the sum of weights must be unity to ensure an unbiased interpolator), $d\left(S_{0}, S_{i}\right)=$ distance from the new point to a known sample point i, $\beta=$ coefficient used to adjust the weights, $n=$ total number of points in the neighbourhood analysis.

IDW produces surfaces by establishing a neighbourhood search of points and weighting these points by a power function. The advantage of IDW is that it works best with evenly distributed points and is sensitive to outliers (Selvam et al. 2014).
Table 1 Standard limits of water quality parameters and the weight of each chemical parameter used for calculating water quality index for drinking and irrigation purposes

\begin{tabular}{|c|c|c|c|c|c|}
\hline \multirow[t]{2}{*}{ Parameter } & \multirow[t]{2}{*}{ Unit } & \multicolumn{2}{|l|}{ Drinking } & \multicolumn{2}{|l|}{ Irrigation } \\
\hline & & Standard limit & Weight & Standard limit & Weight \\
\hline $\mathrm{pH}$ & - & 8.5 & 4 & 7.5 & 4 \\
\hline $\mathrm{EC}$ & $\mu \mathrm{S} \mathrm{cm}-1$ & 1000 & 5 & 2250 & 5 \\
\hline $\mathrm{HCO}_{3}^{-}$ & $\mathrm{mg} / \mathrm{L}$ & - & - & 150 & 2 \\
\hline Total alkalinity & & 250 & 3 & 200 & 4 \\
\hline $\mathrm{Cl}^{-}$ & & 200 & 3 & 250 & 3 \\
\hline $\mathrm{NO}_{3}^{-}$ & & 45 & 5 & 10 & 5 \\
\hline Total hardness & & 500 & 2 & 100 & 4 \\
\hline $\mathrm{Ca}^{2+}$ & & 75 & 2 & 300 & 2 \\
\hline $\mathrm{Mg}^{2+}$ & & 50 & 2 & 30 & 2 \\
\hline $\mathrm{Na}^{+}$ & & 200 & 2 & 200 & 3 \\
\hline $\mathrm{K}^{+}$ & & 12 & 1 & 12 & 2 \\
\hline Residual sodium carbonate (RSC) & $\mathrm{meq} / \mathrm{L}$ & - & - & 2.5 & 5 \\
\hline Sodium adsorption ratio (SAR) & - & - & - & 10 & 5 \\
\hline $\mathrm{Na}(\%)$ & $\%$ & - & - & 40 & 5 \\
\hline Kelly's index & - & - & - & 1 & 5 \\
\hline Permeability index & - & - & - & 75 & 5 \\
\hline
\end{tabular}




\section{Statistical analyses}

The mean and standard error for all physicochemical parameters was calculated. A two-way analysis of variance (ANOVA) was performed to check the variations among the analysed physicochemical parameters in the four zones and two seasons. In addition, non-metric multidimensional scaling and cluster analysis was performed using PAST v.3.21 software to determine the sources responsible for physicochemical parameters.

\section{Results and discussion}

\section{Surface water chemistry}

The mean and standard error of different physicochemical parameters in the four zones of the river during preand post-monsoon seasons of the years 2017 and 2018 are given in Table 2. Two-way ANOVA between different zones and seasons showed a significant interaction between the seasons and zones for $\mathrm{pH}, \mathrm{EC}, \mathrm{CO}_{3}{ }^{2-}, \mathrm{HCO}_{3}{ }^{-}$,

Table 2 Average and standard error of physiochemical parameters of water samples collected from Sutlej river during pre- and post-monsoon seasons of the years 2017 and 2018

\begin{tabular}{|c|c|c|c|c|c|c|c|c|c|c|c|c|c|}
\hline$\overline{\text { Zone }}$ & Parameter & $\mathrm{pH}$ & $\begin{array}{l}\mathrm{EC} \\
\mu \mathrm{S} \mathrm{cm} \mathrm{cm}^{-1}\end{array}$ & $\begin{array}{l}\mathrm{CO}_{3}{ }^{2-} \\
\mathrm{mg} / \mathrm{L}\end{array}$ & $\mathrm{HCO}_{3}^{-}$ & Alkalinity & $\mathrm{Cl}^{-}$ & $\mathrm{NO}_{3}^{-}$ & Total hardness & $\mathrm{Ca}^{2+}$ & $\mathrm{Mg}^{2+}$ & $\mathrm{Na}^{+}$ & $\mathrm{K}^{+}$ \\
\hline \multicolumn{14}{|c|}{ Pre-monsoon season, 2017} \\
\hline \multirow[t]{2}{*}{ Zone-I } & Average & 7.68 & 234 & 14.4 & 37.8 & 58.4 & 18.9 & 1.98 & 65.1 & 16.0 & 6.08 & 12.8 & 5.50 \\
\hline & S.E & 0.05 & 4.18 & 1.47 & 4.88 & 1.67 & 2.37 & 0.80 & 2.89 & 1.16 & 1.22 & 0.14 & 0.15 \\
\hline \multirow[t]{2}{*}{ Zone-II } & Average & 7.68 & 307 & 32.9 & 56.5 & 91.3 & 22.3 & 2.45 & 92.0 & 23.6 & 8.30 & 24.5 & 7.03 \\
\hline & S.E & 0.03 & 25.5 & 2.55 & 6.10 & 6.65 & 5.69 & 0.27 & 3.54 & 1.20 & 0.61 & 5.33 & 1.00 \\
\hline \multirow[t]{2}{*}{ Zone-III } & Average & 7.48 & 547 & 54.1 & 179 & 158 & 29.8 & 4.01 & 96.7 & 26.9 & 7.62 & 24.1 & 6.95 \\
\hline & S.E & 0.02 & 19.7 & 7.00 & 12.8 & 7.79 & 2.67 & 0.33 & 12.6 & 3.50 & 1.30 & 3.25 & 0.74 \\
\hline \multirow[t]{2}{*}{ Zone-IV } & Average & 7.54 & 647 & 38.3 & 160 & 224 & 43.9 & 4.56 & 116 & 32.0 & 9.45 & 31.0 & 9.73 \\
\hline & S.E & 0.03 & 60.2 & 2.57 & 10.9 & 13.1 & 12.2 & 0.29 & 15.8 & 4.06 & 1.34 & 4.20 & 1.52 \\
\hline \multicolumn{14}{|c|}{ Post-monsoon season, 2017} \\
\hline \multirow[t]{2}{*}{ Zone-I } & Average & 7.81 & 258 & 32.4 & 81.7 & 40.0 & 14.2 & 1.80 & 60.0 & 12.4 & 7.05 & 5.20 & 5.80 \\
\hline & S.E & 0.09 & 13.2 & 7.25 & 34.1 & 1.56 & 1.09 & 0.12 & 2.79 & 1.34 & 1.73 & 0.96 & 0.13 \\
\hline \multirow[t]{2}{*}{ Zone-II } & Average & 7.62 & 415 & 38.2 & 111 & 141 & 20.7 & 1.70 & 138 & 33.7 & 12.9 & 14.7 & 6.32 \\
\hline & S.E & 0.03 & 32.9 & 3.47 & 11.6 & 12.1 & 2.57 & 0.11 & 10.51 & 2.80 & 0.99 & 1.31 & 0.48 \\
\hline \multirow[t]{2}{*}{ Zone-III } & Average & 7.53 & 441 & 40.4 & 93.2 & 133 & 23.0 & 1.61 & 131 & 29.2 & 14.0 & 15.7 & 5.82 \\
\hline & S.E & 0.04 & 25.6 & 4.26 & 11.2 & 8.18 & 2.21 & 0.07 & 7.33 & 2.02 & 0.89 & 1.21 & 0.41 \\
\hline \multirow[t]{2}{*}{ Zone-IV } & Average & 7.59 & 478 & 35.3 & 91.8 & 153 & 23.5 & 1.71 & 145 & 33.9 & 14.6 & 18.2 & 6.26 \\
\hline & S.E & 0.04 & 31.6 & 3.52 & 15.1 & 9.66 & 3.35 & 0.07 & 10.34 & 2.73 & 1.21 & 1.21 & 0.56 \\
\hline \multicolumn{14}{|c|}{ Pre-monsoon season, 2018} \\
\hline \multirow[t]{2}{*}{ Zone-I } & Average & 8.05 & 278 & 20.0 & 36.6 & 67.6 & 4.97 & 0.04 & 144 & 39.3 & 11.2 & 8.50 & 1.26 \\
\hline & S.E & 0.01 & 7.43 & 7.35 & 8.13 & 7.95 & 0.87 & 0.00 & 4.00 & 1.50 & 0.97 & 0.84 & 0.12 \\
\hline \multirow[t]{2}{*}{ Zone-II } & Average & 8.04 & 272 & 21.3 & 54.4 & 81.4 & 18.6 & 0.07 & 138 & 37.3 & 10.9 & 9.68 & 2.37 \\
\hline & S.E & 0.04 & 5.41 & 0.99 & 2.21 & 1.57 & 1.89 & 0.00 & 4.33 & 1.05 & 0.89 & 0.71 & 0.17 \\
\hline \multirow[t]{2}{*}{ Zone-III } & Average & 8.30 & 322 & 27.6 & 72.5 & 111 & 33.6 & 0.09 & 160 & 48.8 & 9.27 & 28.7 & 6.2 \\
\hline & S.E & 0.03 & 25.6 & 2.06 & 8.78 & 6.37 & 5.60 & 0.00 & 5.36 & 1.99 & 1.13 & 3.69 & 0.89 \\
\hline \multirow[t]{2}{*}{ Zone-IV } & Average & 8.84 & 338 & 53.4 & 160 & 187 & 23.3 & 0.08 & 156 & 39.7 & 13.7 & 59.2 & 15.3 \\
\hline & S.E & 0.04 & 34.6 & 10.9 & 42.5 & 13.8 & 3.27 & 0.01 & 7.14 & 1.91 & 1.32 & 6.51 & 1.95 \\
\hline \multicolumn{14}{|c|}{ Post-monsoon season, 2018} \\
\hline \multirow[t]{2}{*}{ Zone-I } & Average & 8.14 & 202 & 19.2 & 22.0 & 50.0 & 132 & 42.6 & 3.19 & 30.5 & 13.6 & 4.92 & 2.36 \\
\hline & S.E & 0.11 & 2.28 & 1.53 & 1.49 & 2.24 & 4.90 & 0.00 & 0.15 & 2.04 & 2.26 & 0.11 & 0.05 \\
\hline \multirow[t]{2}{*}{ Zone-II } & Average & 7.84 & 319 & 28.5 & 37.6 & 77.5 & 168 & 47.0 & 2.37 & 43.9 & 14.1 & 14.0 & 3.99 \\
\hline & S.E & 0.03 & 13.0 & 1.53 & 3.27 & 3.46 & 6.99 & 3.22 & 0.24 & 1.94 & 1.22 & 1.51 & 0.34 \\
\hline \multirow[t]{2}{*}{ Zone-III } & Average & 7.81 & 391 & 29.8 & 36.8 & 78.8 & 176 & 64.1 & 4.10 & 42.1 & 17.3 & 34.7 & 6.44 \\
\hline & S.E & 0.05 & 23.0 & 1.59 & 4.31 & 2.49 & 5.91 & 3.63 & 0.19 & 1.40 & 1.60 & 3.00 & 0.48 \\
\hline \multirow[t]{2}{*}{ Zone-IV } & Average & 8.48 & 706 & 31.2 & 13.3 & 78.1 & 201 & 117 & 3.22 & 41.1 & 24.0 & 98.6 & 5.37 \\
\hline & S.E & 0.06 & 156 & 7.96 & 2.30 & 4.94 & 38.6 & 35.5 & 0.17 & 3.37 & 7.42 & 35.3 & 0.81 \\
\hline
\end{tabular}


total alkalinity, $\mathrm{Ca}^{2+}$ and total hardness, but no significant interaction for $\mathrm{Mg}^{+2}, \mathrm{Na}^{+}, \mathrm{K}^{+}, \mathrm{Cl}^{-}$and $\mathrm{NO}_{3}{ }^{-}$(Table 3). These results imply that the variations in $\mathrm{Mg}^{+2}, \mathrm{Na}^{+}, \mathrm{K}^{+}$, $\mathrm{Cl}^{-}$and $\mathrm{NO}_{3}{ }^{-}$with zone and season, but there is an interaction of zone and season on the variations in $\mathrm{pH}, \mathrm{EC}$, $\mathrm{CO}_{3}{ }^{2-}, \mathrm{HCO}_{3}{ }^{-}$, total alkalinity, $\mathrm{Ca}^{2+}$ and total hardness. Selvam et al. (2014) also found the higher concentration of $\mathrm{Cl}^{-}$and $\mathrm{Na}^{+}$in water samples during pre-monsoon season than post-monsoon season. The river water was alkaline in nature with an average $\mathrm{pH}$ of 7.60 during pre-monsoon 2017, 7.76 during post-monsoon 2017, 8.31 during premonsoon 2018 and 8.07 during post-monsoon 2018. There was no significant effect of the monsoon season on $\mathrm{pH}$ of water. The $\mathrm{pH}$ of the water was significantly $(p<0.05)$ higher in Zone 1 than in Zone-III during pre-monsoon 2017 and 2018 and post-monsoon 2017. However, pH was significantly higher along Zone-IV than along Zone-III. High $\mathrm{pH}$ values may be due to the dissolution of cations in the surface water due to anthropogenic waste (Zhang et al. 2016). Electrical conductivity was significantly $(p<0.05)$ higher in Zone-IV than in Zone-I; however, EC of water was generally in the order: Zone-IV $>$ Zone-III $>$ ZoneII $>$ Zone-I (Table 2). EC was higher during pre-monsoon than post-monsoon of the year 2017, but it was lower during pre-monsoon than during post-monsoon of the year 2018. The alterations in EC values are due to the dumping of industrial effluents in the river water (Kangabam et al. 2017). The concentration of cations in the surface water of the river was in the order: $\mathrm{Ca}^{2+}>\mathrm{Na}^{+}>\mathrm{Mg}^{2+}>\mathrm{K}^{+}$
(Table 2). Both $\mathrm{Ca}^{2+}$ and $\mathrm{Mg}^{2+}$ are abundant elements in the surface water and primarily occur in the bicarbonate form (Ravikumar et al. 2011). Compared with Zone-I, total hardness $\left(\mathrm{Ca}^{2+}\right.$ and $\left.\mathrm{Mg}^{2+}\right)$ was highest in Zone-IV followed by Zone-III and Zone-II. The $\mathrm{Na}^{+}$and $\mathrm{K}^{+}$content in the water of the river is contributed from sewage and agricultural runoff (Ravindra and Kaushik 2003). However, there was no significant effect of season on $\mathrm{Na}^{+}$ concentration in water, but the concentration of $\mathrm{K}^{+}$was higher during pre-monsoon than a post-monsoon season. Total alkalinity is a measurement of the counteracting ability of acid in the river water, and the major species for alkalinity in water are $\mathrm{CO}_{3}{ }^{2-}$ and $\mathrm{HCO}_{3}{ }^{-}$(Singh et al. 2012). The carbonate and bicarbonate concentration in water may be due to the dissolution of carbonate minerals. Total alkalinity was significantly $(p<0.05)$ higher during pre-monsoon than post-monsoon during both the years, and it was higher along transboundary (Zone-IV) of the river (Table 2). There was no marked effect of season on $\mathrm{Cl}^{-}$and $\mathrm{NO}_{3}{ }^{-}$concentration in water. Compared with Zone-I, the concentration of these two anions was higher in Zone-IV. Urban sewerage and household wastage are the main sources of $\mathrm{Cl}^{-}$in the river water. $\mathrm{NO}_{3}{ }^{-}$is one of the significant parameters of river water quality which signifies the pollution and anthropogenic inputs in surface water of the river from pesticide and fertilizers usage (Suthar et al. 2009). The regression analysis of EC with cations $\left(\mathrm{Ca}^{2+}, \mathrm{Na}^{+}, \mathrm{Mg}^{2+}\right.$, and $\left.\mathrm{K}^{+}\right)$and anions $\left(\mathrm{CO}_{3}{ }^{2-}\right.$, $\mathrm{HCO}_{3}{ }^{-}, \mathrm{Cl}^{-}$and $\left.\mathrm{NO}_{3}{ }^{-}\right)$indicated that regression coefficient
Table 3 Two-way ANOVA for water quality parameters of the Sutlej river

\begin{tabular}{|c|c|c|c|c|c|c|}
\hline \multirow[t]{2}{*}{ Parameter } & \multicolumn{3}{|c|}{$F$ Value } & \multicolumn{3}{|c|}{$P$ Value } \\
\hline & Zone & Season & Zone $\times$ Season & Zone & Season & Zone $\times$ Season \\
\hline $\mathrm{pH}$ & 11.0 & 46.3 & 15.1 & 0.000 & 0.000 & 0.000 \\
\hline $\mathrm{EC}$ & 6.53 & 305 & 15.8 & 0.000 & 0.004 & 0.020 \\
\hline $\mathrm{CO}_{3}^{2-}$ & 2.00 & 6.56 & 0.39 & 0.117 & 0.000 & 0.858 \\
\hline $\mathrm{HCO}_{3}^{-}$ & 3.64 & 2.03 & 1.20 & 0.000 & 0.020 & 0.310 \\
\hline Total alkalinity & 11.8 & 5.88 & 2.52 & 0.000 & 0.001 & 0.032 \\
\hline $\mathrm{Cl}^{-}$ & 3.27 & 1.34 & 0.53 & 0.023 & 0.263 & 0.756 \\
\hline $\mathrm{NO}_{3}^{-}$ & 3.81 & 6.15 & 0.97 & 0.011 & 0.001 & 0.439 \\
\hline Total hardness & 7.75 & 2.39 & 3.47 & 0.000 & 0.071 & 0.005 \\
\hline $\mathrm{Ca}^{2+}$ & 5.49 & 5.86 & 3.59 & 0.001 & 0.001 & 0.004 \\
\hline $\mathrm{Mg}^{2+}$ & 4.74 & 0.65 & 1.71 & 0.003 & 0.587 & 0.136 \\
\hline $\mathrm{Na}^{+}$ & 5.25 & 3.35 & 0.46 & 0.002 & 0.021 & 0.807 \\
\hline $\mathrm{K}^{+}$ & 1.83 & 0.36 & 1.43 & 0.040 & 0.050 & 0.215 \\
\hline RSC & 7.47 & 12.2 & 2.04 & 0.000 & 0.000 & 0.077 \\
\hline SAR & 4.69 & 3.81 & 0.70 & 0.004 & 0.011 & 0.628 \\
\hline $\mathrm{Na}(\%)$ & 11.7 & 17.8 & 1.64 & 0.000 & 0.000 & 0.153 \\
\hline KI & 3.63 & 4.39 & 1.38 & 0.014 & 0.005 & 0.237 \\
\hline PI & 3.21 & 18.9 & 1.04 & 0.025 & 0.000 & 0.397 \\
\hline WQI for drinking & 9.55 & 2.26 & 0.97 & 0.000 & 0.083 & 0.439 \\
\hline WQI for irrigation & 4.34 & 2.47 & 1.28 & 0.006 & 0.064 & 0.276 \\
\hline
\end{tabular}


Table 4 Average and standard error of residual sodium carbonate (RSC), sodium adsorption ratio (SAR), sodium percentage (Na \%), Kelly's index (KI), permeability index (PI) and water quality index (WQI) of water samples collected from Sutlej river during pre-and post-monsoon seasons of the years 2017 and 2018

\begin{tabular}{|c|c|c|c|c|c|c|c|c|}
\hline \multirow[t]{2}{*}{ Zone } & \multirow[t]{2}{*}{ Parameter } & \multirow[t]{2}{*}{$\mathrm{RSC}(\mathrm{meq} / \mathrm{L})$} & \multirow[t]{2}{*}{ SAR } & \multirow[t]{2}{*}{$\mathrm{Na}(\%)$} & \multirow[t]{2}{*}{$\mathrm{KR}$} & \multirow[t]{2}{*}{ PI } & \multicolumn{2}{|l|}{ WQI } \\
\hline & & & & & & & Drinking & Irrigation \\
\hline \multicolumn{9}{|c|}{ Pre-monsoon season, 2017} \\
\hline \multirow[t]{2}{*}{ Zone-I } & Average & -0.13 & 0.69 & 27.8 & 0.43 & 74.7 & 27.0 & 37.6 \\
\hline & S.E & 0.03 & 0.01 & 0.77 & 0.02 & 1.77 & 0.44 & 1.18 \\
\hline \multirow[t]{2}{*}{ Zone-II } & Average & -0.03 & 1.05 & 29.1 & 0.53 & 60.5 & 33.3 & 40.7 \\
\hline & S.E & 0.10 & 0.19 & 2.54 & 0.08 & 2.75 & 1.83 & 2.61 \\
\hline \multirow[t]{2}{*}{ Zone-III } & Average & 1.18 & 0.92 & 25.2 & 0.41 & 249 & 43.9 & 62.9 \\
\hline & S.E & 0.29 & 0.12 & 3.12 & 0.05 & 62.39 & 1.00 & 6.86 \\
\hline \multirow[t]{2}{*}{ Zone-IV } & Average & 2.13 & 1.10 & 26.9 & 0.46 & 234 & 52.1 & 69.9 \\
\hline & S.E & 0.42 & 0.14 & 3.31 & 0.06 & 60.33 & 3.31 & 7.27 \\
\hline \multicolumn{9}{|c|}{ Post-monsoon season, 2017} \\
\hline \multirow[t]{2}{*}{ Zone-I } & Average & -0.40 & 0.29 & 14.4 & 0.19 & 47.2 & 26.8 & 31.7 \\
\hline & S.E & 0.12 & 0.02 & 1.17 & 0.02 & 2.46 & 0.78 & 0.73 \\
\hline \multirow[t]{2}{*}{ Zone-II } & Average & 0.07 & 0.53 & 17.5 & 0.23 & 54.1 & 39.1 & 35.5 \\
\hline & S.E & 0.08 & 0.04 & 1.27 & 0.02 & 2.17 & 1.33 & 0.80 \\
\hline \multirow[t]{2}{*}{ Zone-III } & Average & 0.04 & 0.60 & 19.5 & 0.27 & 56.9 & 39.1 & 36.4 \\
\hline & S.E & 0.09 & 0.04 & 1.22 & 0.02 & 2.21 & 2.03 & 1.11 \\
\hline \multirow[t]{2}{*}{ Zone-IV } & Average & 0.16 & 0.67 & 20.9 & 0.29 & 58.1 & 41.7 & 37.8 \\
\hline & S.E & 0.09 & 0.03 & 0.77 & 0.01 & 2.36 & 2.12 & 1.16 \\
\hline \multicolumn{9}{|c|}{ Pre-monsoon season, 2018} \\
\hline \multirow[t]{2}{*}{ Zone-I } & Average & -1.53 & 0.31 & 11.3 & 0.13 & 37.6 & 29.2 & 16.9 \\
\hline & S.E & 0.13 & 0.03 & 1.21 & 0.02 & 2.99 & 0.54 & 0.98 \\
\hline \multirow[t]{2}{*}{ Zone-II } & Average & -1.13 & 0.36 & 12.9 & 0.15 & 43.5 & 30.4 & 20.7 \\
\hline & S.E & 0.08 & 0.03 & 0.72 & 0.01 & 1.23 & 0.44 & 0.59 \\
\hline \multirow[t]{2}{*}{ Zone-III } & Average & -0.97 & 0.97 & 24.9 & 0.38 & 50.2 & 37.3 & 31.1 \\
\hline & S.E & 0.13 & 0.11 & 1.58 & 0.04 & 2.01 & 1.60 & 2.45 \\
\hline \multirow[t]{2}{*}{ Zone-IV } & Average & 0.63 & 2.01 & 41.1 & 0.80 & 70.0 & 45.7 & 60.1 \\
\hline & S.E & 0.15 & 0.15 & 0.94 & 0.04 & 1.28 & 2.92 & 4.10 \\
\hline \multicolumn{9}{|c|}{ Post-monsoon season, 2018} \\
\hline \multirow[t]{2}{*}{ Zone-I } & Average & -1.64 & 0.19 & 7.38 & 0.08 & 28.7 & 28.7 & 19.7 \\
\hline & S.E & 0.09 & 0.01 & 0.35 & 0.00 & 1.63 & 0.20 & 0.64 \\
\hline \multirow[t]{2}{*}{ Zone-II } & Average & -1.80 & 0.47 & 14.32 & 0.18 & 34.9 & 35.5 & 23.2 \\
\hline & S.E & 0.11 & 0.05 & 1.15 & 0.02 & 1.40 & 1.01 & 0.93 \\
\hline Zone-III & Average & -1.99 & 1.11 & 26.98 & 0.42 & 40.9 & 41.3 & 34.0 \\
\hline & S.E & 0.11 & 0.10 & 1.60 & 0.04 & 1.65 & 1.39 & 1.53 \\
\hline Zone-IV & Average & -2.52 & 2.10 & 28.39 & 0.57 & 42.4 & 56.6 & 34.7 \\
\hline & S.E & 0.69 & 0.65 & 4.21 & 0.13 & 3.23 & 10.9 & 4.16 \\
\hline
\end{tabular}

( $\beta$ value) was significant with $\mathrm{Ca}^{2+}, \mathrm{K}^{+}$and $\mathrm{HCO}_{3}{ }^{-}$during pre-monsoon $2017, \mathrm{Ca}^{2+}, \mathrm{Na}^{+}$and $\mathrm{HCO}_{3}{ }^{-}$during postmonsoon 2017, and $\mathrm{Ca}^{2+}, \mathrm{Na}^{+}, \mathrm{HCO}_{3}{ }^{-}$and $\mathrm{Cl}^{-}$during preand post-monsoon 2018. These results suggest that river's water chemistry is heterogeneous and affected by geochemical processes and complex contamination sources.

\section{River water for drinking purposes}

The $\mathrm{pH}$ of surface water in all the zones was within the desirable and acceptable limits recommended by WHO (2017).
It was found that $4.8 \%$ of the samples during pre-monsoon $2017,8.4 \%$ during pre-monsoon 2018 , and $7.8 \%$ during postmonsoon 2018 surpassed the EC limits suggested by WHO (2017). The concentration of $\mathrm{CO}_{3}{ }^{2-}$ and $\mathrm{HCO}_{3}{ }^{-}$in surface water was lesser than the limits defined by WHO (2017); however, $4.7 \%$ of the samples exceeded the permissible limit of $\mathrm{HCO}_{3}{ }^{-}$concentration in water during pre-monsoon 2018. Total alkalinity surpassed the permissible limit of WHO in $11.9 \%$ of the samples during pre-monsoon $2017,7.9 \%$ of the samples during post-monsoon 2017 , and $7.5 \%$ of the samples during pre-monsoon 2018. The $\mathrm{Cl}^{-}$concentration in water surpassed the permissible limit defined by WHO 


\section{Drinking - Pre-monsoon, 2017}



Drinking - Pre-monsoon, 2018

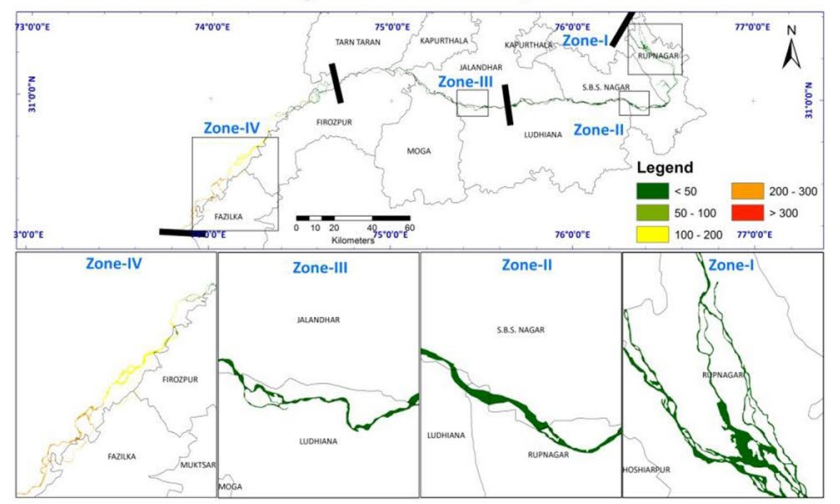

Drinking - Post-monsoon, 2017

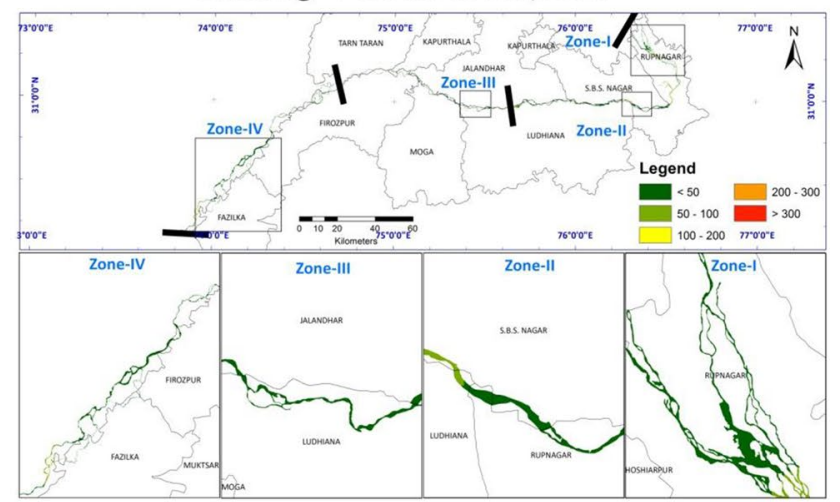

Drinking - Post-monsoon, 2018

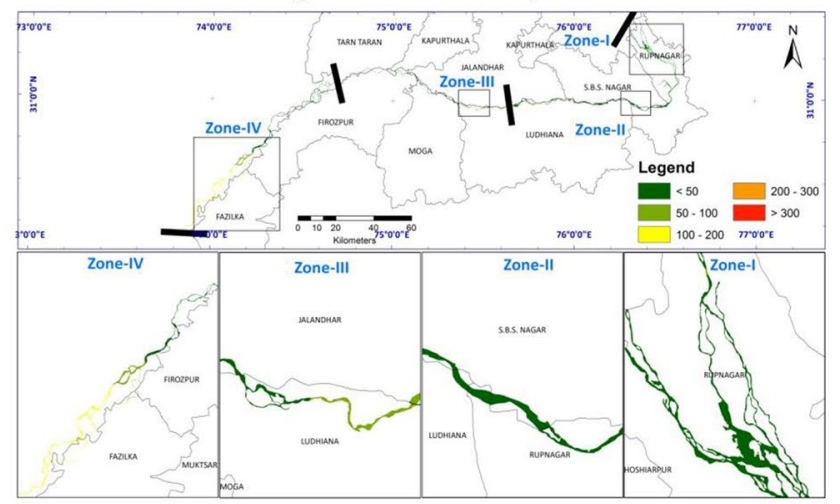

Fig. 2 Spatio-temporal variations in water quality index (for drinking purposes) of water samples collected from the Sutlej river

in $4.8 \%$ of the samples during pre-monsoon 2017, whereas $\mathrm{Cl}^{-}$concentration was higher than the permissible limit in $7.5 \%$ samples during pre-monsoon 2018 , and $4.9 \%$ samples during post-monsoon 2018. The concentration of $\mathrm{NO}_{3}{ }^{-}$was within the permissible limits in surface water samples of the river, irrespective of the season. A higher concentration of $\mathrm{NO}_{3}{ }^{-}$in water may cause blue baby disease/methemoglobinaemia in children and gastric carcinomas (Ward et al. 2018). Total hardness was not within the permissible limit in $3.7 \%$ and $2.9 \%$ of the samples during pre-and post-monsoon 2018. The concentration of $\mathrm{Na}^{+}$in water surpassed the WHO limits in $6.5 \%$ and $4.9 \%$ samples during pre-and postmonsoon 2018, respectively, whereas it was lesser than the WHO limit during pre-and post-monsoon 2017. It was found that $13.1 \%$ of the samples during pre-monsoon $2017,8.9 \%$ samples during post-monsoon 2017, $19.6 \%$ samples during pre-monsoon 2018 and $6.9 \%$ samples during post-monsoon 2018 surpassed the permissible limit of $\mathrm{K}^{+}$in water.

The WQI values were in the order: Zone-I $<$ ZoneII $<$ Zone-III $<$ Zone-IV (Table 4 and Fig. 2). According to grades of WQI for drinking purposes, our results showed that $81.6 \%, 78.2 \%, 91.6 \%$ and $87.3 \%$ samples were excellent during pre-2017, post-2017, pre-2018, and post-monsoon
2018, respectively, whereas $15.5 \%, 21.8 \%, 0.9 \%$ and $6.9 \%$ samples were good during pre-2017, post-2017, pre-2018, and post-monsoon 2018, respectively. The poor WQI was observed in $3.6 \%, 3.7 \%$ and $5.9 \%$ of the samples during pre2017, pre-2018 and post-monsoon 2018, respectively. The very poor WQI was observed in $3.7 \%$ of the samples premonsoon 2018 only.

The Sutlej river water is getting contaminated along its course by domestic sewage, agricultural runoff and industrial wastes. The lower values of WQI in Zone-I may be due to little human activity in this zone, whereas the contaminants from industry, sewage sludge from domestic wastes, fertilizers and pesticides may be the sources of contaminates in the Zones II, III and IV. In Zone-III, there are mainly electroplating and dyeing units in the catchment area of the river which are one of the causes of contamination of the river water. The Zone-IV is mainly transboundary of the river which is mainly separated by physical features, but transboundary aquifers are connected through a natural sub-surface path of groundwater. There are reports that municipal and industrial wastewater drainage across transboundary to the river through wastewater drain also increased the concentration of ions in the Zone-IV of river (Tabinda et al. 2013). 

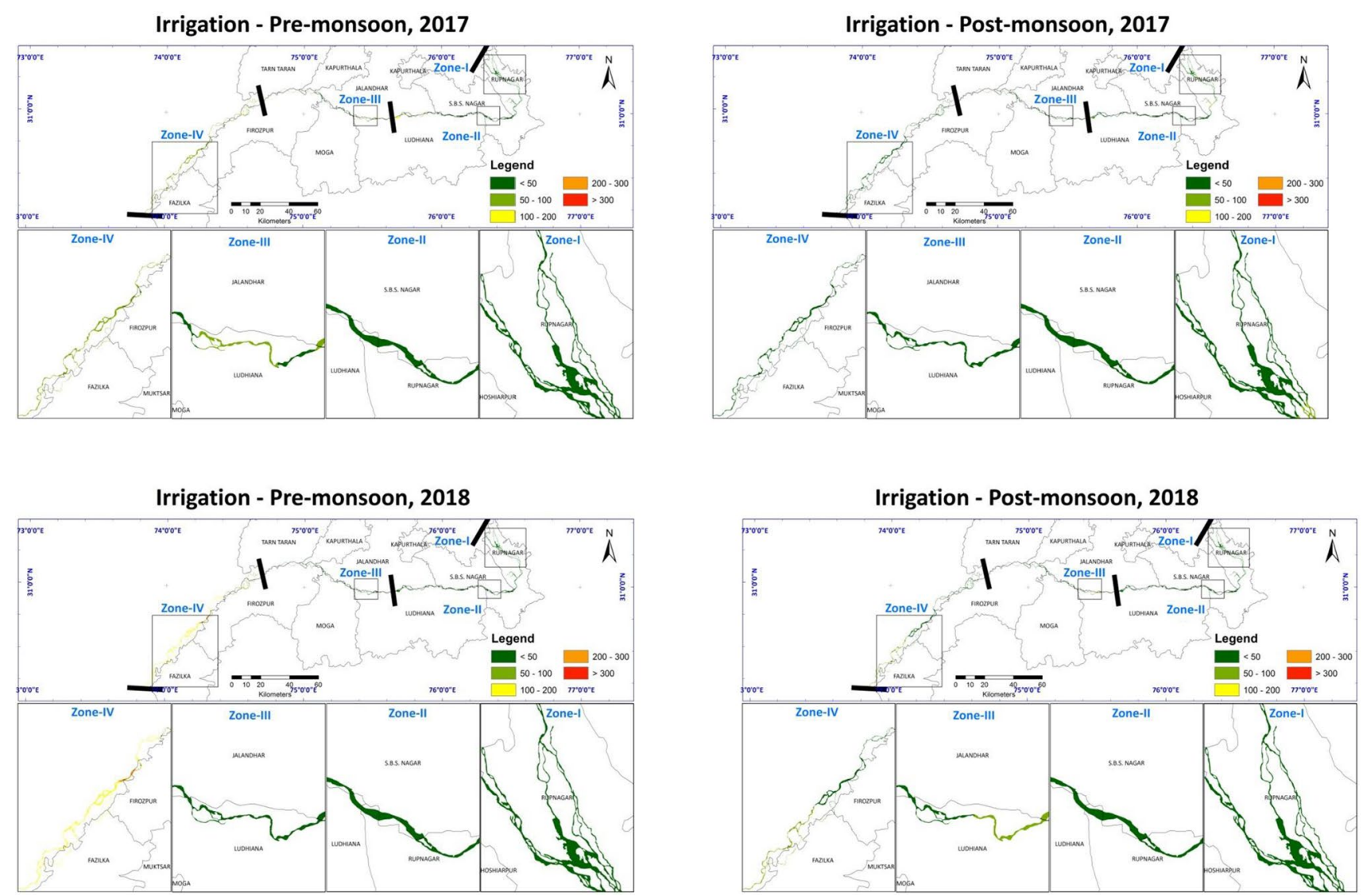

Fig. 3 Spatio-temporal variations in water quality index (for irrigation purposes) of water samples collected from the Sutlej river

\section{River water for irrigation purpose}

According to Bhumbla and Abrol (1972), the major parameters for evaluating water quality for irrigation are EC and RSC. However, SAR, KI and PI are also important. The SAR was lesser than 10 (excellent water) in all the samples of pre-monsoon 2017, post-monsoon 2017 and 2018 (Table 4), but $93.5 \%$ of the samples during pre-monsoon 2018 were within the SAR values of less than 10. RSC was more than $2.5 \mathrm{meq} / \mathrm{L}$ in $13.1 \%$ and $3.7 \%$ of the samples during the premonsoon season of the year 2017 and 2018, respectively. KI was more than one (unsuitable) in $8.3 \%$ of the samples during pre-monsoon $2017,1 \%$ of the samples during post-monsoon $2017,10.3 \%$ of the samples during pre-monsoon 2018 and $7.8 \%$ of the samples during post-monsoon 2018. The PI values were more than 75 (unsuitable) in $31 \%$ of the samples during pre-monsoon $2017,9.9 \%$ of the samples during postmonsoon $2017,6.5 \%$ of the samples during pre-monsoon 2018 and $1 \%$ of the samples during post-monsoon 2018. According to grades of WQI for irrigation purposes, our results showed that $65.5 \%, 94.1 \%, 72.9 \%$ and $90.2 \%$ samples were excellent during pre-2017, post-2017, pre-2018 and post-monsoon 2018 , respectively, whereas $17.9 \%, 5.9 \%$,
$19.6 \%$ and $9.8 \%$ samples were good during pre-2017, post2017 , pre-2018 and post-monsoon 2018 , respectively. The poor WQI was observed in $16.7 \%$ and $4.7 \%$ of the samples during pre-monsoon 2017 and 2018, respectively. The very poor WQI was observed in $2.8 \%$ of the samples pre-monsoon 2018 only. The WQI values were in the order: ZoneI $<$ Zone-II $<$ Zone-III $<$ Zone-IV, irrespective of the season (Fig. 3). The soils of Zone-IV are mainly coarse-textured (mainly sandy) than the other three zones (sandy loam and loam). Under normal irrigation practices, sandy soils can flush more water through the root zone than fine-textured soils (Minhas 1996). Therefore, sandy soils can withstand higher salinity irrigation water because more dissolved salts will be removed from the root zone by leaching (Qadir et al. 2000). The cultivation of crops on the soils along Zone-IV may cause the transfer of ions through the food chain to human beings affecting their health.

\section{Factors controlling the hydrochemistry of the Sutlej river}

There were no significant differences in ion concentration during the pre-monsoon season of the years 2017 and 2018 


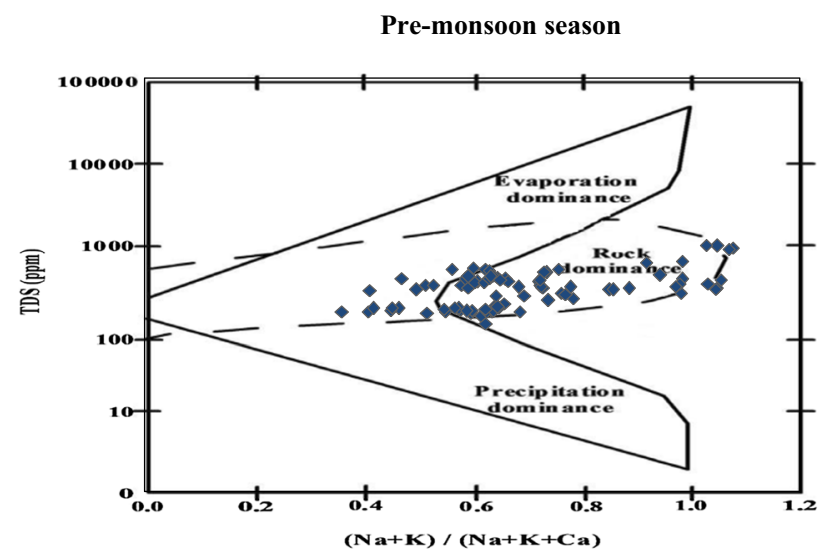

Post-monsoon season

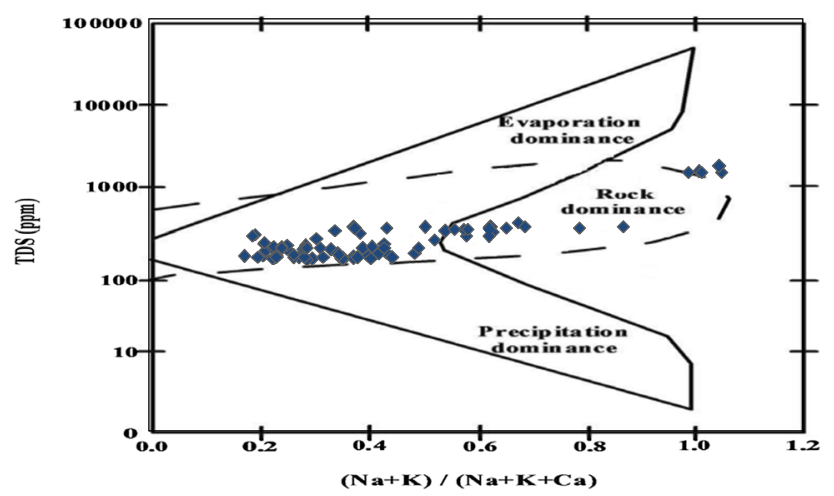

Fig. 4 Major natural processes controlling Sutlej river water chemistry ( Adapted from Gibbs 1970)

and also during the post-monsoon season of both the years. Therefore the data of pre- and post-monsoon season of both years were averaged to study the factors controlling the hydrochemistry using weathering of rocks and multivariate statistics.

The major sources of ions in the river are weathering of rocks and minerals and anthropogenic factors (like domestic sewage, agricultural runoff, and industrial wastes) (Sharma and Subramanian 2008). In the water of the Sutlej river, $\mathrm{HCO}_{3}{ }^{-}$and $\mathrm{Ca}^{2+}$ are the major anion and cation, respectively. $\mathrm{HCO}_{3}{ }^{-}$in river water is considered to be derived from primary carbonates and silicates, whereas $\mathrm{Ca}^{2+}$ from carbonates (Raymahashay 1986). The Gibbs plots showed that weathering of rocks is the main controlling factor that governed the water quality of the Sutlej river (Fig. 4).

The molar ratio of $\mathrm{Ca}^{2+}$ to $\mathrm{Mg}^{2+}$ determines the dissolution of dolomite, calcite and silicate minerals (Singh et al. 2014) When the molar ratio of $\mathrm{Ca}^{2+}$ to $\mathrm{Mg}^{2+}$ is one, it indicates the dissolution of dolomite, but a higher ratio is an indication of greater calcite contribution (Mayo and Loucks 1995). Katz and Hornsby (1998) suggested that the molar ratio of $\mathrm{Ca}^{2+}$ to $\mathrm{Mg}^{2+}$ more than two indicates the dissolution of silicate minerals. In our study, the molar ratio of $\mathrm{Ca}^{2+} / \mathrm{Mg}^{2+}$ in all the four zones of each season suggests the dissolution of calcite and silicate minerals. The average ratio between $\left(\mathrm{Ca}^{2+}+\mathrm{Mg}^{2+}\right)$ and $\left(\mathrm{Na}^{+}+\mathrm{K}^{+}\right)$was more than the world average (2.2), and Indian average (2.5) in Zone-I (4.24 during pre-monsoon and 5.46 during post-monsoon) and Zone-II ( 3.33 during pre-monsoon and 3.66 during postmonsoon) of the river, and this indicates the chemical composition of the river in these two zones is more controlled by the carbonate lithology of the basin. However, this ratio was lesser than the world and Indian average in Zone-IV (1.16 during pre-monsoon and 1.81 during post-monsoon) of the river but variable in Zone-III (1.79 during pre-monsoon and 2.40 during post-monsoon) of the river. This suggests that the chemical composition of the river in Zone-III is controlled by weathering of carbonate and silicate lithology. It was found that water chemistry in the Sutlej river is mainly determined by weathering of carbonates besides silicate minerals. The ratio of $\left(\mathrm{Na}^{+}+\mathrm{K}^{+}\right) / \mathrm{T}_{\mathrm{Z}}^{+}$is used to assess the contribution of cations via silicate weathering (Mehto and Chakrapani 2013; Stallard and Edmond 1987). This average ratio was 1.07 during pre-monsoon 2017, 2.02 during post-monsoon 2017, 1.60 during pre-monsoon 2018 and 1.33 during post-monsoon 2018 . This suggests inputs from the weathering of aluminosilicates. Since $\mathrm{K}^{+}$is the least dominant cation, $\mathrm{Na}^{+}$was more mobile than $\mathrm{K}^{+}$and dominated in the natural solutions during the course of weathering (Sharma and Subramanian 2008).

\section{Non-metric multidimensional scaling and cluster analysis}

Non-metric multidimensional scaling (NMDS) is an indirect gradient assessment technique which generates an ordination based on distance or dissimilarity matrix. In contrast with other approaches which maximize the variance among sampling points in an ordination, NMDS signifies the pair-wise dissimilarity among sampling points in a low-dimensional space. NDMS shows the amount of stress by each distance dissimilarity in the plot. The wide dispersal of points compared with the $1: 1$ line and low coefficient of determination $\left(R^{2}\right)$ values suggest that original dissimilarities are not well preserved in the reduced number of dimensions. NMDS scatter plots for pre- and post-monsoon seasons showed that all the samples are of similar origin except only one sample of the Zone-III during pre-monsoon and post-monsoon excluded the major group (Fig. 5). The water of this location specific sample was taken from the point where there was a confluence of the highly contaminated local drain with the river. The stress values were less than 0.05 during all the seasons, and it signifies a good fit of data to NMDS plot (Kaur et al. 2018). 
(a)

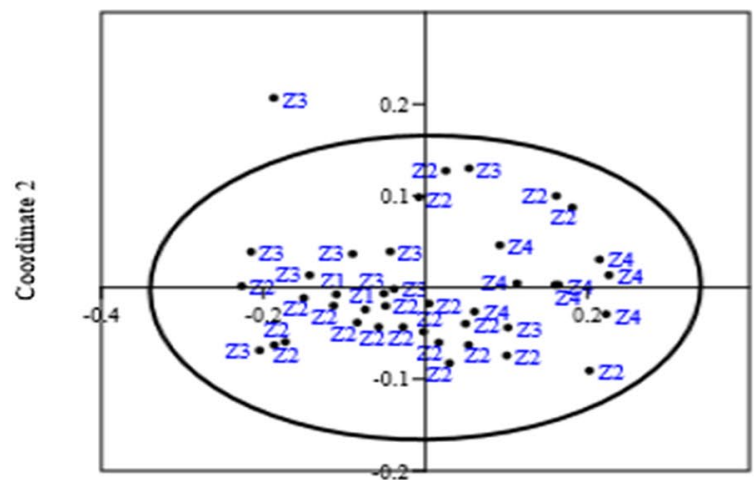

Coordinate 1

(c)

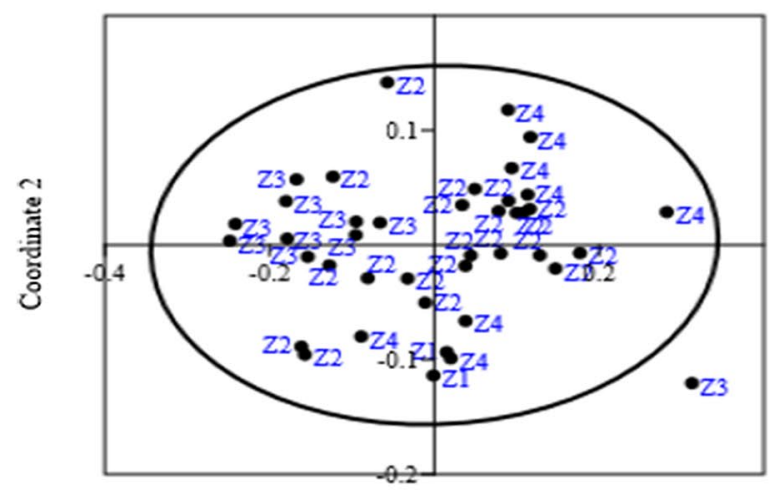

Coordinate 1

Fig. 5 a NMDS scatter plot (95\% eclipse), b NMDS Shepard 2-D plot, stress $=0.04567, R^{2}$ for axis $1=0.7512$ and axis $2=0.1149$ for pre-monsoon season c NMDS scatter plot (95\% eclipse) and d NMDS

Ten variables ( $\mathrm{pH}, \mathrm{EC}, \mathrm{Ca}^{+2}, \mathrm{Mg}^{+2}, \mathrm{Na}^{+}, \mathrm{K}^{+}, \mathrm{CO}_{3}{ }^{-2}$, $\mathrm{HCO}_{3}{ }^{-}, \mathrm{Cl}^{-}$and $\mathrm{NO}_{3}{ }^{-}$) were considered for the cluster analysis. The clustering during pre- and post-monsoon resulted in the two main groups (Fig. 6). During premonsoon, group I comprised $\mathrm{Cl}^{-}$and $\mathrm{pH}$ and group II consisted of $\mathrm{EC}, \mathrm{Ca}^{+2}, \mathrm{Mg}^{+2}, \mathrm{Na}^{+}, \mathrm{K}^{+}, \mathrm{CO}_{3}{ }^{-2}, \mathrm{HCO}_{3}{ }^{-}$and $\mathrm{NO}_{3}{ }^{-}$. The group II is further categorized into $\mathrm{EC}$ and $\mathrm{HCO}_{3}{ }^{-}, \mathrm{K}^{+}, \mathrm{Na}^{+}, \mathrm{NO}_{3}{ }^{-}$and $\mathrm{CO}_{3}{ }^{-2}$, and $\mathrm{Ca}^{+2}$ and $\mathrm{Mg}^{+2}$. During post-monsoon, group I comprised $\mathrm{pH}$, whereas group II had EC, $\mathrm{Ca}^{+2}, \mathrm{Mg}^{+2}, \mathrm{Na}^{+}, \mathrm{K}^{+}, \mathrm{CO}_{3}{ }^{-2}, \mathrm{HCO}_{3}{ }^{-}$, $\mathrm{Cl}^{-}$and $\mathrm{NO}_{3}{ }^{-}$. The group II is further segregated into six subgroups: $\mathrm{EC}, \mathrm{Na}^{+}$and $\mathrm{Cl}^{-}, \mathrm{K}^{+}$and $\mathrm{NO}_{3}{ }^{-}, \mathrm{CO}_{3}{ }^{-2}, \mathrm{Ca}^{+2}$ and $\mathrm{HCO}_{3}{ }^{-}$, and $\mathrm{Mg}^{+2}$. These results suggest the influence of chemical processes in addition to mineral dissolution in the contribution of these ions to the river water. The subgroup between $\mathrm{Na}^{+}$and $\mathrm{Cl}^{-}$indicates that the dissolution of salts is one of the major processes in the river system. (b)

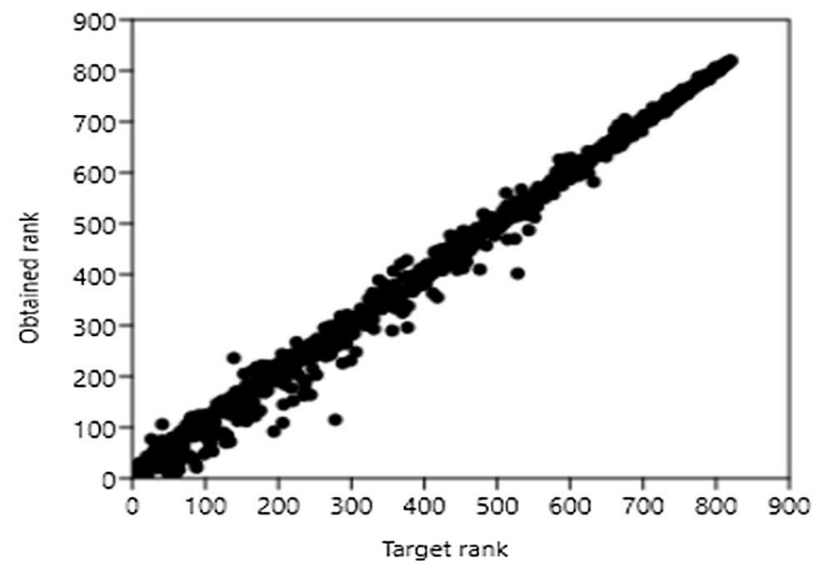

(d)

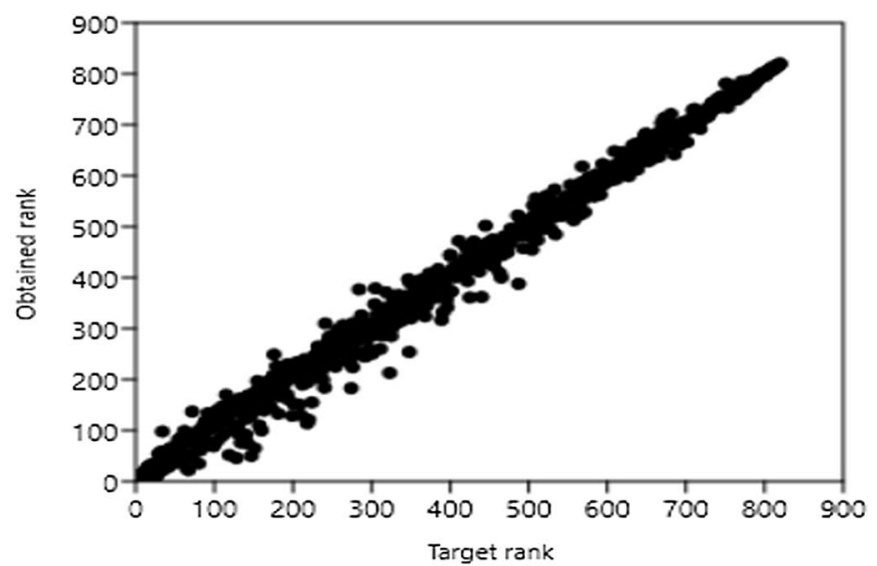

Shepard 2-D plot, stress $=0.04971, R 2$ for axis $1=0.8219$ and axis $2=0.03776$ for post-monsoon season

\section{Conclusions}

The results of this study suggest that the river water is alkaline in nature and the concentration of cations and anions in surface water of the Sutlej river were in the order: $\mathrm{Ca}^{2+}>\mathrm{Na}^{+}>\mathrm{Mg}^{2+}>\mathrm{K}^{+}$and $\mathrm{HCO}_{3}{ }^{-}>\mathrm{Cl}^{-}>\mathrm{CO}_{3}{ }^{2-}>\mathrm{NO}_{3}{ }^{-}$. The concentration of these ions was higher in Zone-IV (along the transboundary of the river). The major sources of ions in the river are weathering of rocks and minerals and anthropogenic factors (like domestic sewage, agricultural runoff and industrial wastes). The Gibbs plots showed that weathering of rocks is the main controlling factor that governed the water quality of the Sutlej river. The ratio of $\mathrm{Ca}^{2+} / \mathrm{Mg}^{2+},\left(\mathrm{Na}^{+}+\mathrm{K}^{+}\right) / \mathrm{T}_{\mathrm{Z}}{ }^{+}$and $\mathrm{Ca}^{2+}+\mathrm{Mg}^{2+} /\left(\mathrm{Na}^{+}+\mathrm{K}^{+}\right)$ in all the four zones indicated that both carbonate and silicate lithology contribute to hydrochemistry of the river besides anthropogenic factors. The WQI values for drinking 

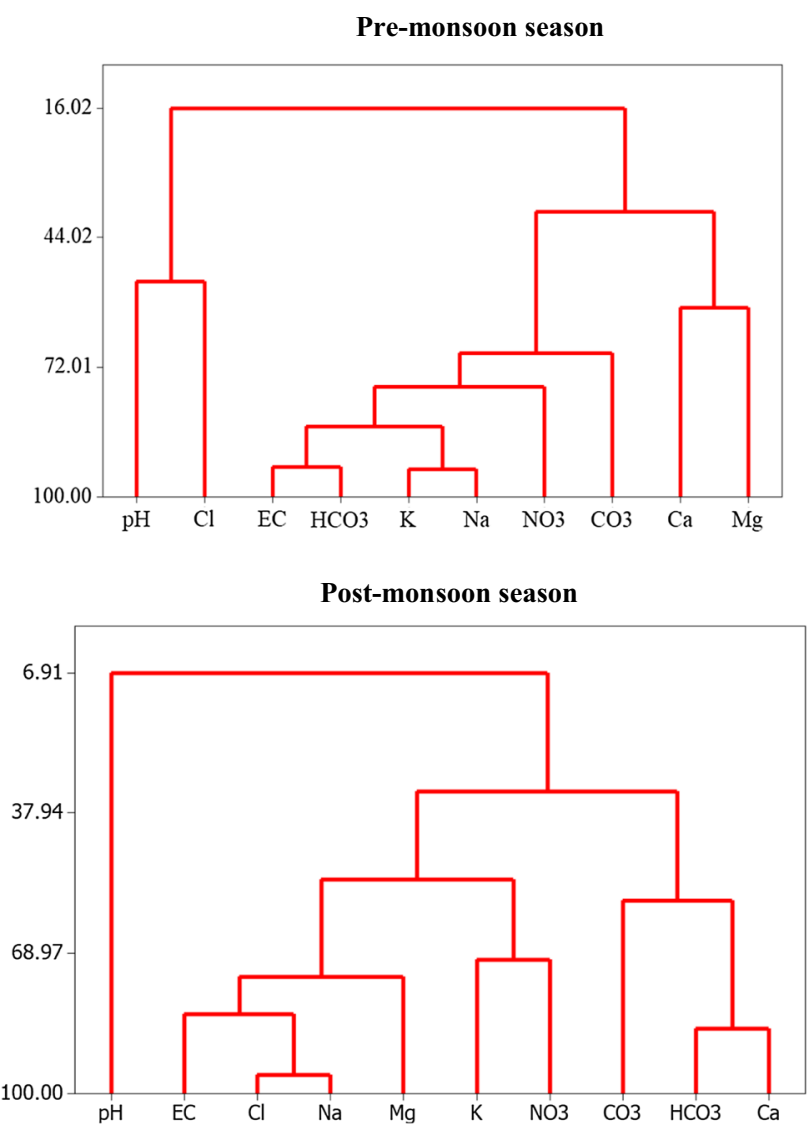

Fig. 6 Cluster analysis of physiochemical parameters for water samples collected from the Sutlej river during pre- and post-monsoon seasons of the years 2017 and 2018

and irrigation were in the order: Zone-I $<$ Zone-II $<$ ZoneIII $<$ Zone-IV. Non-metric multidimensional scaling showed a similar source of origin of ions in the river water. The clustering during pre- and post-monsoon resulted in the two main groups. During pre-monsoon, group I comprised $\mathrm{Cl}^{-}$and $\mathrm{pH}$, and the group II consisted of EC, $\mathrm{Ca}^{+2}, \mathrm{Mg}^{+2}$, $\mathrm{Na}^{+}, \mathrm{K}^{+}, \mathrm{CO}_{3}{ }^{-2}, \mathrm{HCO}_{3}^{-}$and $\mathrm{NO}_{3}{ }^{-}$. During post-monsoon, group I comprised $\mathrm{pH}$, whereas group II had $\mathrm{EC}, \mathrm{Ca}^{+2}$, $\mathrm{Mg}^{+2}, \mathrm{Na}^{+}, \mathrm{K}^{+}, \mathrm{CO}_{3}{ }^{-2}, \mathrm{HCO}_{3}{ }^{-}, \mathrm{Cl}^{-}$and $\mathrm{NO}_{3}{ }^{-}$. These results suggest the influence of chemical processes in addition to mineral dissolution in the contribution of these ions to the river water. The subgroup between $\mathrm{Na}^{+}$and $\mathrm{Cl}^{-}$indicates that the dissolution of salts is one of the major processes in the river system and the anthropogenic factors contribute significantly to affect the water quality of the Sutlej river. The government, communities and industries should meet the water quality goals for safeguarding the environment against adverse biological effects for current and future generations.
Acknowledgements The authors are thankful to the Space Applications Centre, ISRO, Government of India, for providing funds to carry out this study.

Funding The authors are thankful to the Space Applications Centre, ISRO, Government of India, for providing funds to carry out this study.

\section{Declarations}

Conflict of interest The authors declare that they have no known competing financial interests/personal relationships/conflict of interest with anyone that could have appeared to influence the work reported in this paper.

Informed consent All the authors are well informed about the compliance of ethical standards.

Open Access This article is licensed under a Creative Commons Attribution 4.0 International License, which permits use, sharing, adaptation, distribution and reproduction in any medium or format, as long as you give appropriate credit to the original author(s) and the source, provide a link to the Creative Commons licence, and indicate if changes were made. The images or other third party material in this article are included in the article's Creative Commons licence, unless indicated otherwise in a credit line to the material. If material is not included in the article's Creative Commons licence and your intended use is not permitted by statutory regulation or exceeds the permitted use, you will need to obtain permission directly from the copyright holder. To view a copy of this licence, visit http://creativecommons.org/licenses/by/4.0/.

\section{References}

Aravindan S, Shankar K (2011) Groundwater quality in Paravanar River Sub-Basin, Cuddalore District, Tamil Nadu. India J Indian Soc Remote Sens 39:565-581

APHA (American Public Health Association (1998) Standard methods for the examination of water and wastewater, 20th edn. American Public Health Association/American Water Works Association/ Water Environment Federation, Washington

Balamurugan P, Kumar P, Shankar K, Nagavinothini R, Sajil Kumar P (2020) Impact of climate and anthropogenic activities on groundwater quality for domestic and irrigation purposes in Attur region, Tamilnadu, India. Desalination Water Treat 208:172-195

Bauder J, Brock T (2001) Irrigation water quality, soil amendment, and crop effects on sodium leaching. Arid Land Res Manag $15: 101-113$

Bhumbla D, Abrol I (1972) Is your water suitable for irrigation? Get It Tested Indian Farming 22:15-17

Burrough P (2001) GIS and geostatistics: essential partners for spatial analysis. Environ Ecol Stat 8:361-377

Carr GM, Neary JP (2008) Water quality for ecosystem and human health. UNEP/Earthprint.

Chabuk A, Al-Madhlom Q, Al-Maliki A, Al-Ansari N, Hussain HM, Laue J (2020) Water quality assessment along Tigris River (Iraq) using water quality index (WQI) and GIS software. Arab J Geosci $13: 1-23$ 
Curtin D, Steppuhn H, Selles F (1993) Plant responses to sulfate and chloride salinity: growth and ionic relations. Soil Sci Soc Am J 57:1304-1310

Elgallal M, Fletcher L, Evans B (2016) Assessment of potential risks associated with chemicals in wastewater used for irrigation in arid and semiarid zones: a review. Agric Water Manag 177:419-431

Gao L, Wang Z, Shan J, Chen J, Tang C, Yi M (2017) Aquatic environmental changes and anthropogenic activities reflected by the sedimentary records of the Shima River, Southern China. Environ Pollut 224:70-81

Haji M, Karuppannan S, Qin D, Shube H, Kawo NS (2021) Potential human health risks due to groundwater fluoride contamination: A case study using multi-techniques approaches (GWQI, FPI, GIS, HHRA) in Bilate River Basin of Southern Main Ethiopian Rift. Ethiopia Arch Environ Contam Toxicol 80:277-293

Hounslow A (1995) Water quality data: analysis and interpretation. CRC Press, Lewis Publishers, Boca Raton

Jiang Y, Gui H, Yu H, Wang M, Fang H, Wang C, Chen C, Zhang Y, Huang Y (2020) Hydrochemical characteristics and water quality evaluation of rivers in different regions of cities: a case study of Suzhou City in Northern Anhui Province. China Water 12:950

Jindal R, Sharma C (2011) Studies on water quality of Sutlej River around Ludhiana with reference to physicochemical parameters. Environ Monit Assess 174:417-425

Kamble BS, Saxena PR, Kurakalva RM, Shankar K (2020) Evaluation of seasonal and temporal variations of groundwater quality around Jawaharnagar municipal solid waste dumpsite of Hyderabad city, India. SN Appl Sci 2:1-22

Kangabam RD, Bhoominathan SD, Kanagaraj S, Govindaraju M (2017) Development of a water quality index (WQI) for the Loktak Lake in India. Appl Water Sci 7:2907-2918

Katz BG, Hornsby HD (1998) A preliminary assessment of sources of nitrate in springwaters, Suwannee River Basin, Florida. U.S. Geological Survey. Open-File Report 98-69

Kaur R, Kaur R, Sharma A, Kumar V, Sharma M, Bhardwaj R, Thukral AK (2018) Microbial production of dicarboxylic acids from edible plants and milk using GC-MS. J Anal Sci Technol 9:21

Kawo NS, Shankar K (2018) Groundwater quality assessment using water quality index and GIS technique in Modjo River Basin, central Ethiopia. J African Earth Sci 147:300-311

Kazi T, Arain M, Jamali MK, Jalbani N, Afridi H, Sarfraz R, Baig J, Shah AQ (2009) Assessment of water quality of polluted lake using multivariate statistical techniques: a case study. Ecotoxicol Environ Saf 72:301-309

Kelly W (1940) Permissible composition and concentration of irrigated waters. Proc ASCF 607:607-613

Khatri N, Tyagi S (2015) Influences of natural and anthropogenic factors on surface and groundwater quality in rural and urban areas. Front Life Sci 8:23-39

Logeshkumaran A, Magesh N, Godson PS, Chandrasekar N (2015) Hydro-geochemistry and application of water quality index (WQI) for groundwater quality assessment, Anna Nagar, part of Chennai City, Tamil Nadu, India. Appl Water Sci 5:335-343

Mainali J, Chang H (2018) Landscape and anthropogenic factors affecting spatial patterns of water quality trends in a large river basin, South Korea. J Hydrol 564:26-40

Mayo AL, Loucks MD (1995) Solute and isotopic geochemistry and ground water flow in the central Wasatch Range, Utah. J Hydrol $172: 31-59$

Mehto A, Chakrapani G (2013) Spatio-temporal variation in the hydrochemistry of Tawa River, Central India: effect of natural and anthropogenic factors. Environ Monit Assess 185:9789-9802

Minhas P (1996) Saline water management for irrigation in India. Agric Water Manag 30:1-24
Mirzaei R, Sakizadeh M (2016) Comparison of interpolation methods for the estimation of groundwater contamination in Andimeshk-Shush Plain, Southwest of Iran. Environ Sci Pollut Res 23:2758-2769

Moral FJ (2010) Comparison of different geostatistical approaches to map climate variables: application to precipitation. Int J Climatol A J Royal Meteorol Soc 30:620-631

Ogbozige F, Adie D, Abubakar U (2018) Water quality assessment and mapping using inverse distance weighted interpolation: a case of River Kaduna, Nigeria. Niger J Technol 37:249-261

Pande CB, Moharir K (2018) Spatial analysis of groundwater quality mapping in hard rock area in the Akola and Buldhana districts of Maharashtra, India. Appl Water Sci 8:1-17

Poudel D, Lee T, Srinivasan R, Abbaspour K, Jeong C (2013) Assessment of seasonal and spatial variation of surface water quality, identification of factors associated with water quality variability, and the modeling of critical nonpoint source pollution areas in an agricultural watershed. J Soil Water Conserv 68:155-171

Qadir M, Ghafoor A, Murtaza G (2000) Amelioration strategies for saline soils: a review. Land Degrad Dev 11:501-521

Ravikumar P, Somashekar R, Angami M (2011) Hydrochemistry and evaluation of groundwater suitability for irrigation and drinking purposes in the Markandeya River basin, Belgaum District, Karnataka State, India. Environ Monit Assess 173:459-487

Ravindra K, Kaushik A (2003) Seasonal variations in physico-chemical characteristics of River Yamuna in Haryana and its ecological best-designated use. J Environ Monit 5:419-426

Raymahashay B (1986) Geochemistry of bicarbonate in river water. J Geol Soc India 27:114-118

Richards L (1954) Diagnosis and improvement of saline and alkali soils. Handbook No. 60. US Department of Agriculture, Washington, DC.

Rodríguez R, Pastorini M, Etcheverry L, Chreties C, Fossati M, Castro A, Gorgoglione A (2021) Water-quality data imputation with a high percentage of missing values: a machine learning approach. Sustainability 13:6318

Selvakumar S, Chandrasekar N, Kumar G (2017) Hydrogeochemical characteristics and groundwater contamination in the rapid urban development areas of Coimbatore, India. Water Resour Ind 17:26-33

Selvam S, Manimaran G, Sivasubramanian P, Balasubramanian N, Seshunarayana T (2014) GIS-based evaluation of water quality index of groundwater resources around Tuticorin coastal city, South India. Environ Earth Sci 71:2847-2867

Setia R, Dhaliwal SS, Kumar V, Singh R, Kukal SS, Pateriya B (2020) Impact assessment of metal contamination in surface water of Sutlej River (India) on human health risks. Environ Pollut 265:114907

Setia R, Dhaliwal SS, Singh R, Kumar V, Taneja S, Kukal SS, Pateriya B (2020) Phytoavailability and human risk assessment of heavy metals in soils and food crops around Sutlej river. India. Chemosphere 263:128321

Setia R, Lamba S, Chander S, Kumar V, Dhir N, Sharma M, Singh R, Pateriya B (2021) Hydrochemical evaluation of surface water quality of Sutlej river using multi-indices, multivariate statistics and GIS. Environ Earth Sci 80:1-17

Shahabi A, Malakouti M, Fallahi E (2005) Effects of bicarbonate content of irrigation water on nutritional disorders of some apple varieties. J Plant Nutr 28:1663-1678

Shankar K, Aravindan S, Rajendran S (2010) GIS based groundwater quality mapping in Paravanar river sub-basin, Tamil Nadu, India. Int J Geomat Geosci 1:282-296

Sharma N, Walia YK (2017) A Study to assess the water quality of Satluj River at Wajipur Kalan, Ludhiana, Punjab. Asian J Adv Basic Sci 5:08-13 
Sharma SK, Subramanian V (2008) Hydrochemistry of the Narmada and Tapti rivers, India. Hydrol Process: an Int J 22:3444-3455

Singh A, Sharma S (2020) Water Pollution due to discharge of industrial effluents in Sutlej river and its impact on groundwater. Int J Res Appl Sci Eng Technol 8:327-357

Singh C, Rina K, Singh R, Mukherjee S (2014) Geochemical characterization and heavy metal contamination of groundwater in Satluj River Basin. Environ Earth Sci 71:201-216

Singh CK, Shashtri S, Singh A, Mukherjee S (2011) Quantitative modeling of groundwater in Satluj River basin of Rupnagar district of Punjab using remote sensing and geographic information system. Environ Earth Sci 62:871-881

Singh D, Singh V, Agnihotri A (2013) Study of textile effluent in and around Ludhiana district in Punjab, India. Int J Environ Sci 3:1271-1278

Singh VK, Bikundia DS, Sarswat A, Mohan D (2012) Groundwater quality assessment in the village of Lutfullapur Nawada, Loni, District Ghaziabad, Uttar Pradesh, India. Environ Monit Assess 184:4473-4488

Spencer RG, Aiken GR, Wickland KP, Striegl RG, Hernes PJ (2008) Seasonal and spatial variability in dissolved organic matter quantity and composition from the Yukon River basin. Alaska Global Biogeochem Cycles 22(GB4002):1-13

Stallard R, Edmond J (1987) Geochemistry of the Amazon: 3. Weathering chemistry and limits to dissolved inputs. J Geophys Res Oceans 92:8293-8302

Sundaray SK, Nayak BB, Bhatta D (2009) Environmental studies on river water quality with reference to suitability for agricultural purposes: Mahanadi river estuarine system, India-a case study. Environ Monit Assess 155:227-243

Suthar S, Nema AK, Chabukdhara M, Gupta SK (2009) Assessment of metals in water and sediments of Hindon River, India: impact of industrial and urban discharges. J Hazard Mater 171:1088-1095

Tabinda AB, Bashir S, Yasar A, Munir S (2013) Heavy metals concentrations in water, sediment and fish in river Sutlej at Sulemanki headworks. Pak J Zool 45:1663-1668

Todd D K, and Mays L W (2005) Groundwater hydrology. Hoboken, NJ, Wiley

Ward MH, Jones RR, Brender JD, De Kok TM, Weyer PJ, Nolan BT, Villanueva CM, Van Breda SG (2018) Drinking water nitrate and human health: an updated review. Int J Environ Res Public Health 15:1557

Warrence NJ, Bauder JW, Pearson KE (2002) Basics of salinity and sodicity effects on soil physical properties. Departement of Land Resources and Environmental Sciences, Montana State University-Bozeman, MT

White P, Brown P (2010) Plant nutrition for sustainable development and global health. Ann Bot 105:1073-1080

White PJ, Broadley MR (2001) Chloride in soils and its uptake and movement within the plant: a review. Ann Bot 88:967-988

WHO (World Health Organization) (2017) Guidelines for Drinkingwater Quality: Fourth Edition Incorporating the First Addendum. WHO, Geneva

Wilcox LV (1955) Classification and use of irrigation waters, US Department of Agriculture. Circ. 969. Washington, DC

Yang W, Zhao Y, Wang D, Wu H, Lin A, He L (2020) Using principal components analysis and IDW interpolation to determine spatial and temporal changes of surface water quality of Xin' anjiang river in Huangshan, China. Int J Environ Res Public Health 17:2942

Yegemova S, Kumar R, Abuduwaili J, Ma L, Samat A, Issanova G, Ge Y, Kumar V, Keshavarzi A, Rodrigo-Comino J (2018) Identifying the key information and land management plans for water conservation under dry weather conditions in the Border areas of the Syr Darya River in Kazakhstan. Water 10:1754

Zaman M, Shahid SA, Heng L (2018) Irrigation water quality. Guideline for salinity assessment, mitigation and adaptation using nuclear and related techniques. Springer, pp 113-131

Zhang B, Song X, Zhang Y, Ma Y, Tang C, Yang L, Wang Z-L (2016) The interaction between surface water and groundwater and its effect on water quality in the Second Songhua River basin, northeast China. J Earth Syst. Sci. 125:1495-1507

Publisher's Note Springer Nature remains neutral with regard to jurisdictional claims in published maps and institutional affiliations. 